\title{
CONSUMER ENGAGEMENT IN AN ONLINE BRAND COMMUNITY
}

\author{
HANNA KURIKKO \\ Faculty of Management and Business \\ University of Tampere \\ 33014 Tampere \\ Finland \\ hanna.kurikko@gmail.com \\ PEKKA TUOMINEN \\ Faculty of Management and Business \\ University of Tampere \\ 33014 Tampere \\ Finland \\ pekka.tuominen@tuni.fi
}

\begin{abstract}
This article aims to explore consumer engagement in an online brand community. Consumer engagement includes cognitive, affective and behavioural dimensions.

This qualitative research focuses on the Finnish online forum called Brick Builders. This community is fully fan-based without any company involvement and it includes different age groups and both genders. The data collection is mainly based on netnography with more than one thousand postings and with nearly two hundred different poster pseudonymes. However, pure netnographic approach was supplemented by eleven personal interviews and several interactive emails.

This research proposes four main theoretical conclusions. First, to create and sustain tight bonds among the members of an online brand community is vital in social networking. Second, to evangelize and justify are relevant thematic sub-practices in impression management. Third, to reinforcie involvement in the brand community can be facilitated by community engagement. Fourth, to increase and enhance the consumption of the parent brand is typical in brand use.
\end{abstract}

Key words: Consumer Engagement, Online Brand Community, Netnography 


\section{Introduction}

Our social worlds have gone digital. Social media involves participation, interaction, and sharing. Wikipedia, Facebook, MySpace, Second Life, and Instagram are examples of interactive communities. Blogs, podcasts, wikis, and RSS feeds are modern forms of social activity. Social media is an umbrella concept that includes also all kinds of different online communities in cyberspace.

Online communities are no longer new forms of communication and communities; they have become the status quo, the way that our society simply works (Schembri and Latimer 2016). Online and virtual consumer communities are real communities populated with real people (Kozinets 2002; Shang et al. 2006).

The established view of brand management as a linear and exchange-based partnership is no longer entirely valid (Heding et al. 2016). According to Quinton (2013) debate between companies and consumers but also between consumers should be encouraged. Active and open discussions about brands in brand communities - whether positive or negative - should be welcomed in order to develop insight. Brand community characteristics include social, cognitional and emotional dimensions. Social identification is vital in brand communities (Hung and Lin 2015).

A brand community is a specialized, non-geographically bound community that is based on a structured set of social relationships shared by admirers of the brand (Bowden 2009; Hollebeek 2011; McAlexander et al. 2002; Muniz and O'Guinn 2001; Ouwersloot and OdekerkenSchröder 2008; Stokburger-Sauer 2010). Customer engagement can also be characterized by different customer activities and patterns (Fernandes and Esteves 2016; Jaakkola and Alexander 2014).

The motivations for joining a brand community include, e.g. the need to get information about a product or service, to express commitment to a certain brand, and consume something together with others (Narvanen 2013). Madupu and Cooley (2010) have proposed a theoretical model for understanding participating factors in online brand communities.

Recently, based on an extensive literature review Hook et al. (2018) have disclosed different motivations and results for participating brand communities. According to Hook et al. (2018) various motivations for attending brand communities include self, social, information, entertainment, and technology related sub-categories and results include brand, brand community, and social related sub-categories.

The current article aims to explore consumer engagement in an online brand community. The definition of consumer engagement offered by Brodie et al. (2013) is one of the most comprehensive in the marketing literature: consumer engagement represents a highly contextdependent psychological state characterized by a specific intensity level that plays a central role in the process of relational exchange. In addition, customer engagement is a muconstruct with cognitive, affective and behavioural sub-categories (Dessart et al. 2015). The behavioural dimension in customer engagement seems to be dominant in the marketing literature (Gummerus et al. 2012; Hollebeek 2011).

Studies in consumer engagement are gaining popularity in the marketing science (Verhoef et al. 2010; Vivek et al. 2012; Alexander and Jaakkola 2015; Azer and Alexander 2018; Fehrer et al. 2018). Existing research in this area is mainly descriptive or conceptual (Alexander et al. 2018; Li et al. 2018). Baldus et al. (2015) have elaborated and validated empirical scale for online brand community engagement This tentative study contributes to the existing marketing literature by adding empirically proven data to the mainly current conceptual research settings in the area of consumer engagement. 
The structure of this article is as follows. First, we lay grounds and elaborate theoretical foundations for the conceptual framework of this study. Second, the empirical data collection amd principles for the objectivity of this study are presented. In this second section we emphasize that this empirical study utilizes netnography as the principal method of data creation. Finally, empirical findings and theoretical conclusions are elaborated.

\section{Theoretical Foundations for the Conceptual Framework}

A sense of belonging motivates members to be part in a brand community. Thematic practices create value in online brand communities (Skalen et al. 2015). Schau et al. (2009) have identified four main thematic practices of creating value. These main thematic practices include several sub-practices which are elaborated in the empirical part of this study.

The members - or, more specifically, the roles of online brand community members - affect the community's dynamics. According to Kozinets (2010) these roles include lurkers, networkers, interactors and makers. These roles are illustrated in Figure 1.

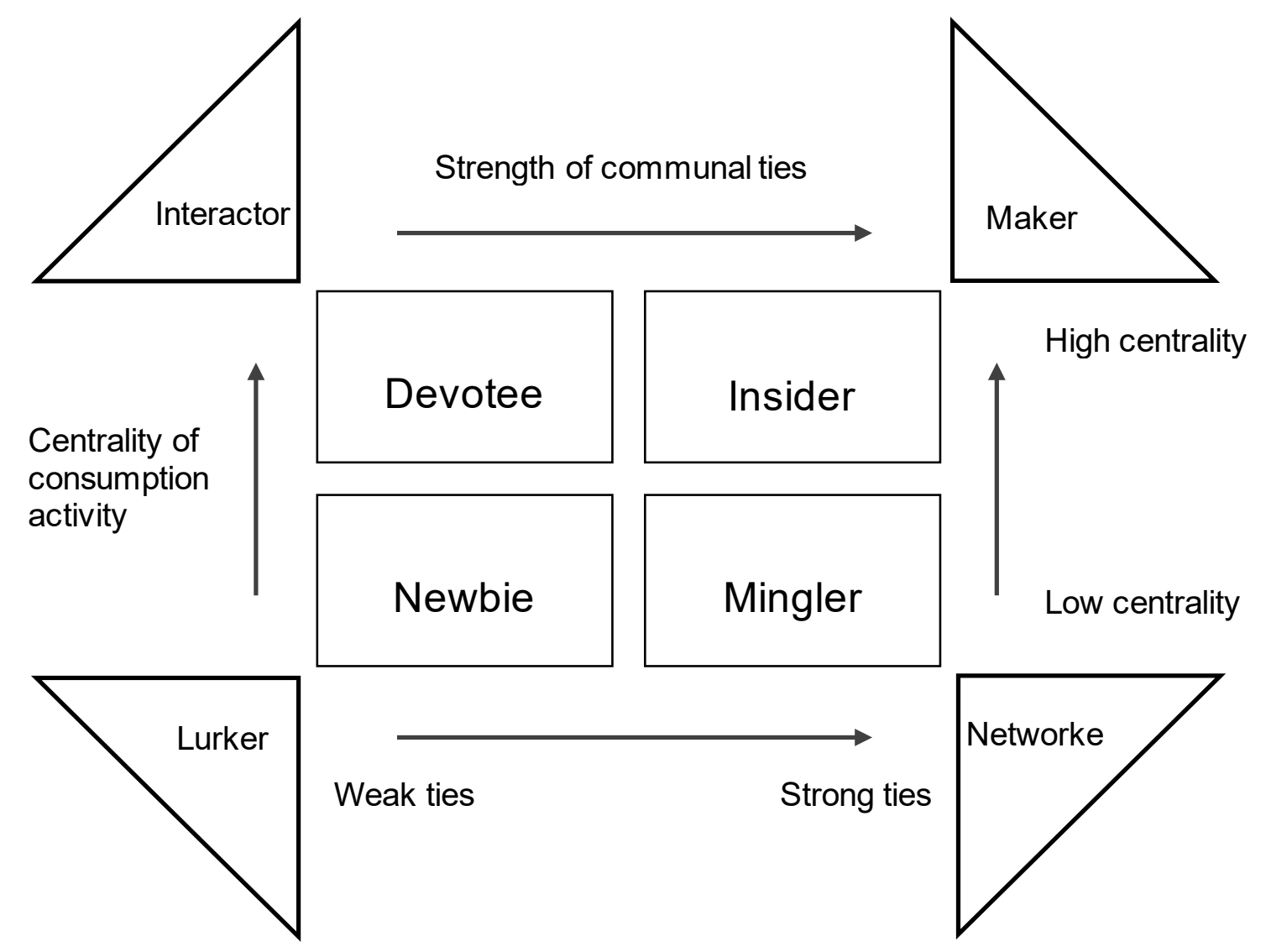

Figure 1. Different roles of online brand community members (Source: Kozinets 2010, p. 33) 
Lurkers are active observers who learn about a site through initially watching. Networkers will reach out to the online brand community in order to communicate and socialize with other participants in the same community. Interactors are heavily engaged with the consumption activity and they offer activity-related news and other information. Makers are active builders of online brand communities. Newbies, minglers, devotees and insiders constitute clear groups of community members based on the centrality of consumption activity and the strength of communal ties (Kozinets 1999; Kozinets 2010).

Consumers are active creators of value. Traditionally, companies have produced products and services while the media have acted as the messenger. Today, value is collectively created by many different stakeholders, for example via social media and brand communities (Alexander et al. 2018; Hook et al. 2018; Jaakkola and Alexander 2014).

Brands influence positively on strengthening customer relationships, and brand communities strengthen the relationship between consumers even more (Carlson et al. 2008; Hollebeek et al. 2014; Lee et al. 2011; Zhou et. al. 2012). Furthermore, brand communities have an impact on brand equity and brand loyalty (Aaker 2013; Keller 2013; Thompson and Sinha 2008).

\section{Empirical Data Collection and Objectivity of the Study}

This empirical and qualitative study focuses on an active Finnish online forum called Palikkatakomo (Brick Builders in English. This fully fan-based online brand community gathers together Finnish LEGO builders from all ages and both genders. This community is fully fanbased without any LEGO-company involvement (Brick Builders 2018). It is also possible to identify in Brick Builders all of Kozinets' (2010) members in the online brand community, namely newbies, minglers, devotees, and insiders.

Empirical data collection is mainly based on netnography with more than one thousand postings and with nearly two hundred different poster pseudonymes. However, pure netnographic approach was supplemented by eleven personal interviews and several interactive emails.

Netnography is well suitable for marketing research because of the wide range of marketing-related topics found in online communities. Netnography assists to find out what consumers are truly like (Kozinets 2006; Kozinets 2015). The netnographic researcher can observe and collect information from online communities, different forums, chats, blogs, and virtual worlds.

Netnography offers of ten wide and accurate opportunities for understanding the customer than traditional data collection methods because netnography is unelicited (Kozinets 2006; Kozinets et al. 2014). Pure netnography can also be supplemented and blended by some forms of ethnography (Kozinets 2010).

The selected online brand community Brick Builders has active and regular communications. It is also interactive and substantial, which means that there is a large flow of communication between participants, a critical mass of communicators, and an energetic feel. There are over 12,000 postings, almost 900 threads, and ten different subject categories in the forum (Brick Builders 2018). This online brand community offers detailed and descriptively rich database for this empirical study.

In this study, 212 pages were printed in 12-point font. These 212 pages represented 1,035 different postings, which contained 197 distinct poster names. Eleven personal interviews were also conducted. 
After data collection this netnographic study includes the data analysis and the iterative interpretation of the empirical findings. A netnographer can use manual coding or qualitative analysis software programs. In this study, the coding was made manually, and both analytic coding and hermeneutic interpretation were used, with hermeneutic interpretation being emphasized.

Kozinets' (2010) ten criteria for objectivity in the netnographic research process were utilized in this study to increase the credibility of empirical findings.

In this study, coherence and rigour refer to how well netnography is understood and utilized to conduct the research. The method and its standards were carefully examined before embarking on the research. Research ethics were also followed by asking permission from the Brick Builders' members to conduct this study.

Literacy refers to the degree to which the text recognizes past relevant literature and research approaches. The literature on online brand communities, and netnography was carefully reviewed. The existing theoretical literature and the Brick Builders' forum were reviewed simultaneously.

Groundedness is the criterion that defines how the theoretical framework is supported by the empirical findings. The theoretical implications found in this study are supported by the Brick Builders' writings. Within Brick Builders, several specific questions to the members of the community and close cooperation with a few members further confirmed the principles of this community and helped to increase objectivity.

Innovation creates new ways of understanding different systems and actions. The phenomenon of the online brand community is quite new. Therefore, this study seeks to extend current knowledge and create new material.

Resonance concerns empathy, compassion, and understanding others. Brick Builders is made by and for humans, and therefore the texts are analysed literally.

Verisimilitude means that the investigator must feel a certain connection to the community or culture in question. He or she must be believable and persuasive. In this study, many members of Brick Builders were also personally met.

Reflexivity means that the texts are left open to criticism and alternative approaches. Other researchers might notice other issues emerging from the data. Subjective interpretation is both a challenge and an opportunity for the netnographer. The reliability has been increased with careful documentation.

Praxis - inspiring social action - is another criterion for ethnographic quality. New technology empowers social action and activism. This study aims to increase understanding of consumer engagement in this research context.

The tenth criterion, intermix, takes into account social interaction both in online and offline modes. Pure netnography was mixed and blended by ethnographic observation with a strong theoretical background. The distinction between pure netnography and pure ethnography is illustrated in Figure 2 (Kozinets 2010). 


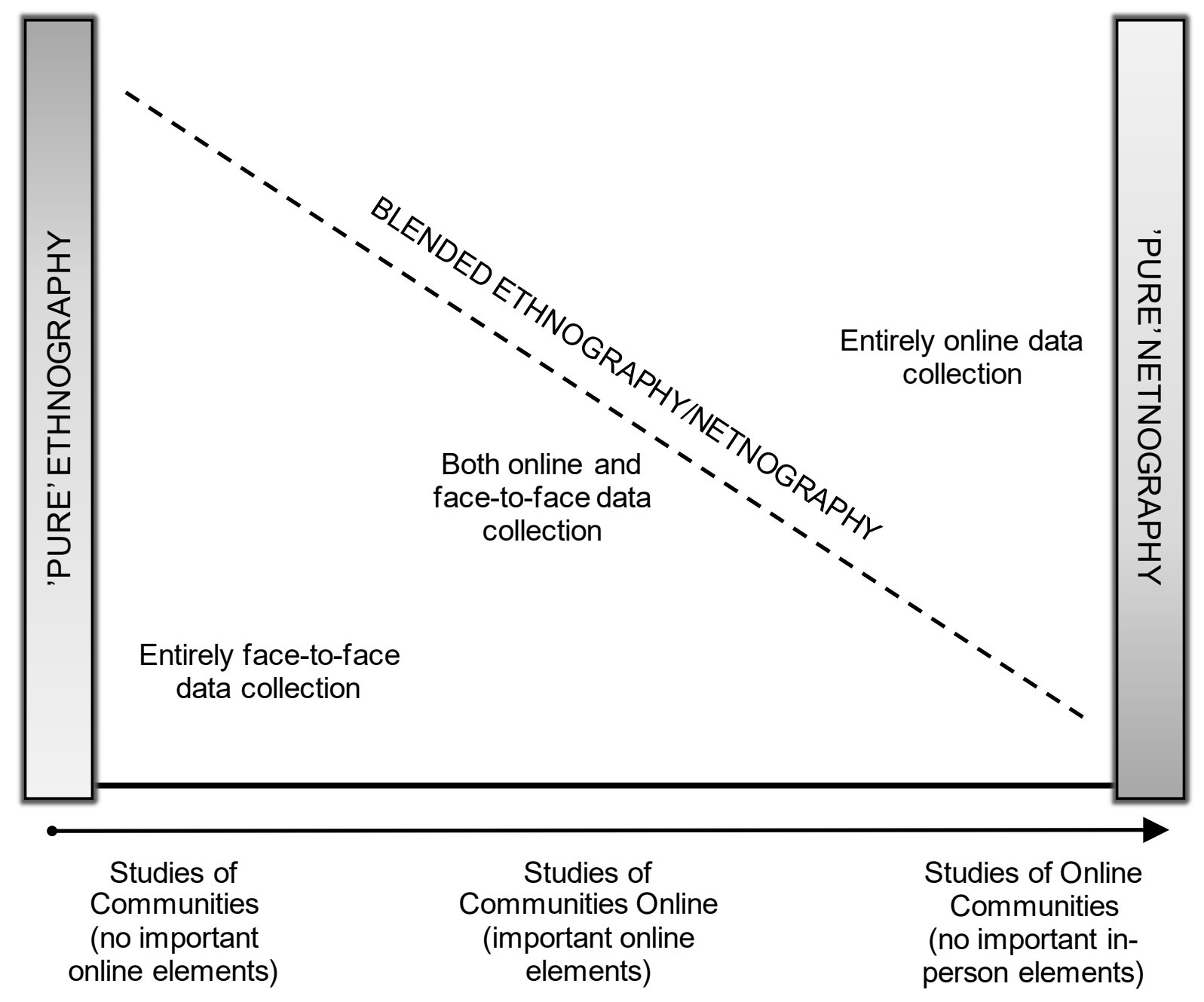

Figure 2. Blending pure netnography and pure ethnography (Source: Kozinets 2010, p. 67)

This study includes blended elements from both pure netnography and ethnography. The data collection is mainly based on netnography with more than one thousand postings and with nearly two hundred different poster pseudonymes. However, pure netnographic approach was supplemented by eleven personal interviews and several interactive emails. In addition, it was possible to attend an exhibition where also Brick Builders' were attending with their own fair stand.

\section{Empirical Findings and Theoretical Conclusions}

According to Schau et al. (2009) social networking, impression management, community engagement and brand use constitute the main thematic practices in brand communities. Empirical findings in our study indicate clearly that in addition to these four main thematic practices numerous sub-practices can be found in Brick Builders as illustrated in Figure 3. 


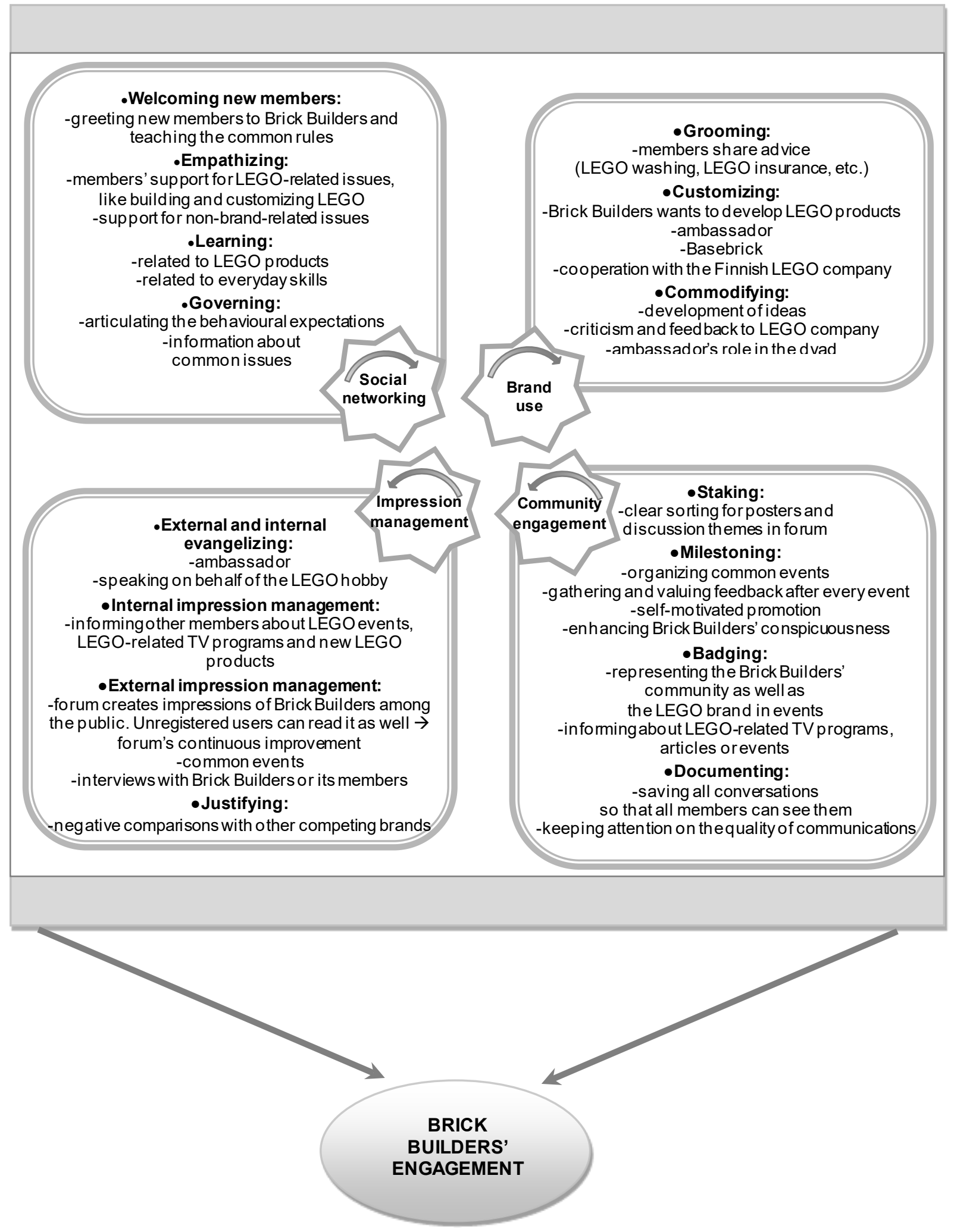

Figure 3. Thematic practices and engagement in Brick Builders (Source: Schau et al. 2009, p. 36 and empirical findings from this case study) 
According to Schau et al. 2009 social networking is a thematic practice that focuses on creating, enhancing, and sustaining ties among online brand community members. The subpractices include welcoming, empathizing, and governing. Impression management practices include evangelizing and justifying. Community engagement practices reinforce members' commitment to the brand community. The sub-practices include staking, milestoning, badging, and documenting. Brand use practices are specifically related to the improved or enhanced use of the focal brand. These sub-practices include grooming, customizing, and commoditizing (Schau et al. 2009, p. 36).

Our theoretical conclusions can be now shortly summarized. First, to create and sustain tight bonds among the members of an online brand community is vital in social networking. It is evident that to welcome, empathize, learn and govern are the corresponding thematic subpractices in this context. Second, to evangelize and justify are relevant thematic sub-practices in impression management. It also includes both internal and external dimensions. Third, to reinforce involvement in the brand community can be facilitated by community engagement. It is apparent that to stake, milestone, badge and document are corresponding thematic subpractices in this occasion. Fourth, to increase and enhance the consumption of the parent brand is characteristic in brand use. It is obvious that to groom, customize, and commodify are the relevant thematic sub-practices in this context.

\section{References}

Aaker, D., 2013. Building Strong Brands. London: Simon and Schuster.

Alexander, M., and Jaakkola, E., 2015. Customer engagement bebaviours and value cocreation, pp. 3-20. In: R. Brodie, L. Hollebeek and J. Conduit, eds. Customer Engagement: Contemporary Issues and Challenges. London: Routledge.

Alexander, M., Jaakkola, E., and Hollebeek, L., 2018. Zooming out: Actor engagement beyond the dyadic. Journal of Service Management, 29(3), pp. 333-351.

Azer, J., and Alexander, M., 2018. Conceptualizing negatively valenced influencing behavior: Forms and triggers. Journal of Service Management, 29(3), pp. 468-490.

Baldus, B., Voorhees, C., and Calantone, R., 2015. Online brand community engagement: Scale development and validation. Journal of Business Research, 68(5), pp. 978-985.

Brick Builders, 2018. Brick Buildes in English, [online] Available at:

<http://www.palikkatakomo.org/static/in-english> [accessed 25 June 2018].

Bowden, J., 2009. The process of customer engagement: A conceptual framework. Journal of Marketing Theory and Practice, 17(1), pp. 63-104.

Brodie, R., Hollebeek, L., Juric, B., and Ilic, A., 2011. Customer engagement: Conceptual domain, fundamental propositions and implications for research. Journal of Service Research, 14(3), pp. 252-271.

Brodie, R., llic, A., Juric, B., and Hollebeek, L., 2013. Consumer engagement in a virtual brand community: An exploratory analysis. Journal of Business Research, 66(1), pp. 105-114.

Carlson, B., Suter, T., and Brown, T., 2008. Social versus psychological brand community: The role of psychological sense of brand community. Journal of Business Research, 61(4), pp. 284-291. 
Dessart, L., Veloutsou, C., and Morgan-Thomas, A., 2015. Consumer engagement in online brand communities: A social media perspective. Journal of Product and Brand Management, 24(1), pp. 28-42.

Fehrer, J., Woratschek, H., Germelmann, C., and Brodie, R., 2018. Dynamics and drivers of customer engagement: Within the dyad and beyond. Journal of Service Management, 29(3), pp. 443-467.

Fernandes, T., and Esteves, F., 2016. Customer engagement and loyalty: A comparative study between service contexts. Services Marketing Quarterly, 37(2), pp.125-139.

Gummerus, J., Liljander, V., Weman, E., and Pihlstrom, M., 2012. Customer engagement in a Facebook brand community. Management Research Review, 35(9), pp. 857-877.

Heding, T., Knudtzen, C., and Bjerre, M., 2016. Brand Management: Research, Theory and Practice. London: Routledge.

Hollebeek, L., 2011. Exploring customer brand engagement: Definition and themes. Journal of Strategic Marketing, 19(7), pp. 555-573.

Hollebeek, L., Glynn, M., and Brodie, R., 2014. Consumer brand engagement in social media: Conceptualization, scale development and validation. Journal of Interactive Marketing, 28(2), pp. 149-165.

Hook, M., Baxter, S., and Kulczynski, A., 2018. Antecedents and consequences of participation in brand communities: A literature review. Journal of Brand Management, 25(4), pp. 277-292.

Hung, H-Y., and Lin, T-L., 2015. A moderated mediation model of consumers' role behaviors in brand communities. Asia Pacific Management Review, 20(3), pp. 191-200.

Jaakkola, E., and Alexander, M., 2014. The role of customer engagement behavior in value co-creation: A service system perspective. Journal of Service Research, 17(3), pp. 247-261.

Keller, K., 2013. Strategic Brand Management. Building, Measuring, and Managing Brand Equity. Boston: Pearson.

Kozinets, R., 1999. E-tribalized marketing? The strategic implications of virtual communities of consumption. European Management Journal, 17(3), pp. 252-264.

Kozinets, R., 2002. The field behind the screen: Using netnography for marketing research in online communities. Journal of Marketing Research, 39(1), pp. 61-72.

Kozinetz, R., 2006. Click to connect: Netnography and tribal advertising. Journal of Advertising Research, 46(3), pp. 279-288.

Kozinets, R., 2010. Netnography. Doing Ethnographic Research Online. London: Sage Publications.

Kozinets, R., 2015. Netnography: Redefined. London: Sage Publications.

Kozinets, R., Dolbec, P-Y., and Earley, A., 2014. Netnographic analysis: Understanding culture through social media, pp. 262-276. In: U. Flinck, ed. The Sage Handbook of Qualitative Data Analysis. London: Sage Publications. 
Lee, H., Lee, C., Taylor, C., and Lee, J., 2011. Do online brand communities help to build and maintain relationships with consumers? A network theory approach. Journal of Brand Management, 19(3), pp. 213-227.

Li, L., Juric, B., and Brodie, R., 2018. Actor engagement valence: Conceptual foundations, propositions and research directions. Journal of Service Management, 29(3), pp. 491-516.

Madupu, V., and Cooley, D., 2010. Antecedents and consequences of online brand community participation: A conceptual framework. Journal of Internet Commerce, 9(2), pp. 127-147.

McAlexander, J., Schouten, J., and Koenig, H., 2002. Building brand community. Journal of Marketing, 66(1), pp. 38-54.

Merz, M., He, Y., and Vargo, S., 2009. The evolving brand logic: A service-dominant logic perspective. Journal of the Academy of Marketing Science, 37(3), pp. 328-344.

Muniz, A., and O'Guinn, T., 2001. Brand community. Journal of Consumer Research, 27(4), pp. 412-432.

Narvanen, E., 2013. Extending the Collective Consumption of Brands. Acta Universitatis Tamperensis 1868. Tampere: Tampere University Press.

Ouwersloot, H., and Odekerken-Schröder G., 2008. Who's who in brand communities and why? European Journal of Marketing, 42(5-6), pp. 571-585.

Quinton, S., 2013. The community brand paradigm: A response to brand management's dilemma in the digital era. Journal of Marketing Management, 29(7-8), pp. 912-932.

Schau, H., Muniz, A., and Arnould, E., 2009. How brand community practices create value. Journal of Marketing, 73(5), pp. 30-51.

Schembri, S., and Latimer, L., 2016. Online brand communities: Constructing and coconstructing brand culture. Journal of Marketing Management, 32(7-8), pp. 628-651.

Shang, R-A., Chen, Y-C., and Liao, H-J., 2006. The value of participation in virtual consumer communities on brand loyalty. Internet Research, 16(4), pp. 398-418.

Skalen, P., Pace, S., and Cova B., 2015. Firm-brand community value co-creation as alignment of practices. European Journal of Marketing, 49(3-4), pp. 596-620.

Stokburger-Sauer, N., 2010. Brand community: Drivers and outcomes. Psychology and Marketing, 27(4), pp. 347-368.

Thompson, S., and Sinha, R., 2008. Brand communities and new product adoption: The influence and limits of oppositional loyalty. Journal of Marketing, 72(6), pp. 65-80.

Verhoef, P., Reinartz, W., and Krafft, M., 2010. Customer engagement as a new perspective in customer management. Journal of Service Research, 13(3), pp. 247-252.

Vivek, S., Beatty, S., and Morgan, R., 2012. Customer engagement: Exploring customer relationships beyond purchase. Journal of Marketing Theory and Practice, 20(2), pp. 127-145.

Zhou, Z., Zhang, Q., Su, C., and Zhou, N., 2012. How do brand communities generate brand relationships? Intermediate mechanisms, Journal of Business Research, 65(7), pp. 890-895. 